\title{
„Scena jest przecież metaforą śruby”: rozmowa z Jackiem Jekielem, dyrektorem Opery na Zamku w Szczecinie
}

DOI: http://dx.doi.org/10.12775/LC.2017.021

Katarzyna Szczerbowska-Prusevicius: 20 maja 2016 roku w Operze na Zamku w Szczecinie odbyla się premiera opery Benjamina Brittena The Turn of the Screw (Dokręcanie śruby). Jest to pierwsza inscenizacja tej opery w Polsce, a zatem wydarzenie szczególne. Wcześniej polscy widzowie mogli tę operę oglądać tylko raz, w roku 1977, w wykonaniu Opery Szkockiej, a w ubiegłym roku, w ramach Festiwalu Beethovenowskiego w Warszawie, można było usłyszeć jej wersję koncertową. Jako dyrektor Opery na Zamku w Szczecinie postanowil Pan przedstawić melomanom utwór Brittena w pełnej postaci. Dlaczego zdecydowal się Pan na realizację tej właśnie opery?

Jacek Jekiel: Czytałem recenzje Festiwalu Beethovenowskiego. Wspaniali polscy recenzenci, jak Dorota Szwarcman z „Polityki” i Jerzy Marczyński z „Rzeczpospolitej” jednym głosem orzekli, że muzyka Benjamina Brittena jest piękna, ale jeszcze piękniej brzmiałaby jako opera. Nie sposób się z nimi nie zgodzić. Opera brzmiałaby bardziej intrygująco, niosłaby za sobą dodatkowe wartości, gdyby była opatrzona scenografią, kostiumami, wokalem, całym entourage'em przynależnym tej królowej sztuk, bo tym jest dla mnie opera. Od razu poczułem, że prowokacyjne, bo tak to odebrałem, komentarze recenzentów - „tylko kto się odważy”, to coś dla mnie i mojego zespołu. Powiedziałem sobie: „ja się odważę, ja to zrobię". Wiedziałem, że będę do tego potrzebował wybitnych artystów, od kierownika muzycznego - choć tu nie muszę się martwić, bo Jerzy Wołosiuk (dyrektor ds. artystycznych Opery na Zamku i kierownik muzyczny Dokręcania śruby) to perfekcjonista czujący operę jak mało kto - przez scenografa, kostiumy, projekcje i oczywiście znakomitą, doskonale przemyślaną reżyserię Natalii Babińskiej. To miał być kameralny spektakl w sensie odbioru merytorycznego, może tak to nazwę, ale wizualnie uderzający widza boleśnie, nawet bardzo boleśnie, tym, co się dzieje, w tym przypadku czymś mrocznym, tajemniczym, złym, zahaczającym właściwie o thriller, a z czym widz musi sobie poradzić tu i teraz. To miało być wspaniałe widowisko! Bo to nie jest opera, do której jesteśmy przyzwyczajeni. To naprawdę nowość, a w Polsce - rzekłbym - eksperyment. W przypadku Brittena dosłownie, bo inscenizacja Dokręcania śruby w Operze na Zamku była zarazem pierwsza w Polsce. Do tego udana. I nie jestem nieskromny. Mamy przecież recenzje, i to nie tylko polskich krytyków. 


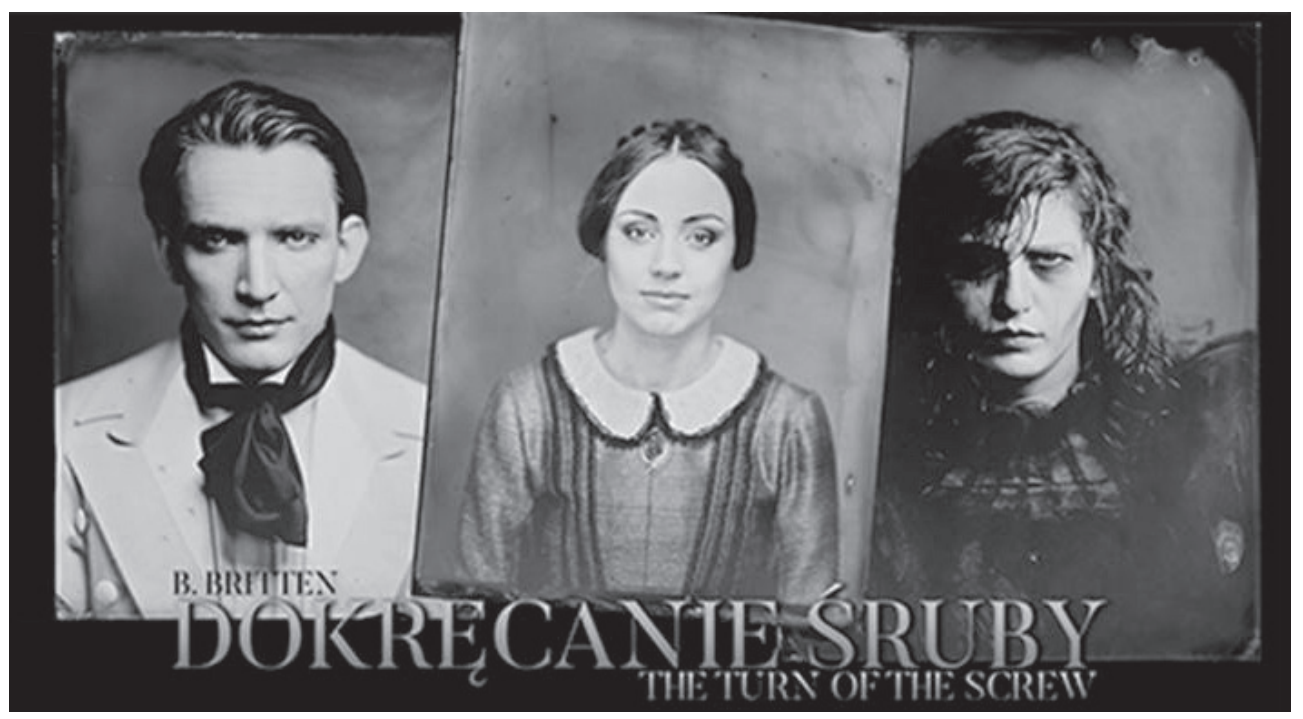

Plakat ze spektaklu Dokręcanie Śruby B. Brittena autorstwa Lexa Drewinskiego.

Opera na Zamku w Szczecinie

Muzyka Brittena jest uwodzicielsko piękna, ale dla widzów przyzwyczajonych do klasycznego, mocno zakorzenionego w systemie dur-moll repertuaru, może być trudna w odbiorze. Mimo że Britten nie rezygnuje calkowicie $z$ tonalności, na pewno przekracza on jej granice, wykorzystuje na przykład serię dwunastotonową jako motyw śruby. Jego język muzyczny odbiega zdecydowanie od języka XVIII i XIX wieku, który ciągle jeszcze ksztaltuje muzyczne przyzwyczajenia większości odbiorców. Takie utwory przeważały zresztą dotychczas $w$ repertuarze Opery na Zamku. Czy wystawienie Brittena wyznacza może nowy kierunek repertuarowy szczecińskiego teatru muzycznego, czy jest raczej pojedynczą przygodą?

To ani kierunek, ani pojedyncza przygoda. Jako dyrektor instytucji kulturalnej tak ważnej nie tylko dla Szczecina, nie tylko dla regionu, ale i dla całego kraju - tu znów dodam: docenianej także za granicą - muszę myśleć o repertuarze w kontekście widowni. Czy zawsze chciałaby oglądać klasykę w tradycyjnej wersji? Zapewne nie, znudziłaby się. Czy zawsze chciałaby oglądać unowocześnioną operę, tak jak to zrobiliśmy ostatnio z Carmen Bizeta? W naszej wersji główna bohaterka nie pracuje w fabryce cygar, których już praktycznie przecież nie ma, bo cygara skręcają maszyny, a na koniec wybiera Escamilla, który u nas nie jest torreadorem, a piłkarzem, współczesnym Ronaldo. Chciałbym jednak wyrwać naszą operę z kleszczy konwencji. Nasz zespół nie boi się ani eksperymentów, ani tradycyjnych arcydzieł. Dodatkowo ja mam szczęście do ludzi, z którymi pracuję, których wybieram do realizacji poszczególnych spektakli. Oni potrafią stworzyć na tyle niepowtarzalną atmosferę na scenie, że zawsze mamy komplety widzów. Jedni wolą tradycję, to naturalne, inni - nowatorstwo, ciągłe poszukiwania. Ja wiem, de gustibus non disputandum est i nie o to tu też chodzi. Chodzi o to, żeby w każdy spektakl włożyć tyle dobrej energii, tyle wysiłku, by widownia zobaczyła przedstawienie dopracowane, dopieszczone, wręcz bezbłędne - bezbłędne w wybranej przez nas stylistyce, naturalnie. Wtedy uwierzy mi, że repertuar dobraliśmy właściwie i uwierzy, że warto do Opery na Zamku przychodzić. Bo tu każdy spektakl jest do końca szczery. 
Melomani mają jeszcze świeżo w pamięci zeszłoroczną wersję koncertową. Jest ona ponadto dostępna $w$ formie albumu płytowego wydanego przez firmę fonograficzną Dux. Wzięli w niej udzial śpiewacy ze Stanów Zjednoczonych i Wielkiej Brytanii. Pan postawił na młodą, polską obsadę (Bożena Bujnicka, która wystąpiła jako Panna Jessel, kończy dopiero studia na Uniwersytecie Muzycznym w Warszawie). Czy mógłby Pan spróbować porównać obydwa wykonania?

Absolutnie jestem przekonany, że nasze wykonanie było po stokroć lepsze. A to z prostego powodu: wykonywanie partii śpiewanych bez ruchu scenicznego, bez operowego entourage'u jest zawsze gorsze. W operze nie tylko słyszymy głos - nie zamykamy też oczu. Otwieramy je szeroko, by zobaczyć, co sugeruje nam dramaturgia, jak aktor dopełnia ruchem ciała swoją postać. Czy boję się porównania jakości? Nie. Nasze młode śpiewaczki co zaznaczają znawcy tematu - potrafią wydobyć dojrzałość i w swoim głosie, i w kreowanej przez siebie postaci.

Nowela Henry'ego Jamesa, na podstawie której powstało libretto, znana jest polskim czytelnikom z przekładu Witolda Pospieszały pod tytułem $W$ kleszczach lęku. Angielski tytuł The Turn of the Screw bywa też tłumaczony dosłownie jako Obrót śruby. Pan zdecydował się na Dokręcanie śruby z nowego przekładu Jacka Dehnela. Ten tytuł chyba bardziej niż poprzedni oddaje charakter angielskiego idiomu, „, a turn of the screw”. Czy prowadzili Państwo dyskusję nad tłumaczeniem tytułu? Co zaważyło o wyborze?

Prowadziliśmy i to bardzo długo. Mam gdzieś jeszcze stary repertuar, gdzie The Turn of the Screw widnieje jako $W$ kleszczach lęku. Zwrot „a turn of the screw” to idiom i nigdy nie będzie można go jednoznacznie przetłumaczyć. Między innymi dlatego zostawiliśmy także angielski tytuł, by każdy widz mógł sam dokonać interpretacji. O tym tłumaczeniu, myślę o zwrocie Dokręcanie śruby zdecydowała pani reżyser, Natalia Babińska. Uznała, że atmosfera tego wiktoriańskiego domu, ten niepokój, to czające się wszędzie zło, ta tajemnica właśnie wspaniale współgra $\mathrm{z}$ takim, a nie innym tytułem. Tu ten ból, strach bohaterów się „dokręca”, a nie „okręca”. To nasza interpretacja, ale zostawiamy ją widzom.

Autorem zapowiadającego operę plakatu jest Lex Drewinski, wybitny polski plakacista, pochodzący zresztą ze Szczecina, obecnie profesor Wydziału Design w Fachhochschule Potsdam (Poczdam). Czy projekt Lexa Drewinskiego uzupełnia wizualnie znaczenia zagubione $w$ polskim tłumaczeniu tytułu? Jego klucz nastawny wydaje się trochę zbyt sympatyczny, by sygnalizować narastające napięcie i grozę. Sympatyczny? Nie wydaje mi się. To przecież klucz, dość ciężki, do tego - mocno chwyta! Ale jeśli Pani tak to odbiera, wyjaśnię tak: czy coś sympatycznego musi do końca, do finału być sympatyczne? Czy przy dokręceniu śruby nie czuć bólu, niepokoju? Czy to, co sympatyczne, nie może przerodzić się w to, co groźne, niebezpieczne? Może, a nawet często tak jest. Przecież nasza bohaterka, guwernantka, na początku jest zachwycona miejscem, do którego przyjechała, potem coraz bardziej „dokręca” ją przerażenie i tajemnicze zło tego domu.

Szczecińska inscenizacja opery uzyskuje swój niepowtarzalny charakter między innymi dzięki scenografii i kostiumom zaprojektowanym przez Martynę Kander. Na 
scenie zamiast mebli pojawiają się ich szkielety. Jakie symboliczne znaczenie kryje się pod tym zabiegiem?

Po pierwsze nadało to lekkości i dynamizmu całej scenografii i takiej, powiedziałbym, prześwietlonej perspektywy. Po drugie scenografka nie chciała kopiować wiktoriańskiego stylu wyposażenia wnętrz. Widziała Pani te projekcje? One wnoszą więcej znaczeń aniżeli prawdziwe meble, prawdziwe jezioro czy prawdziwy krajobraz. Ja jestem zachwycony. W tak kameralnym przedstawieniu wiktoriański przepych byłby jak zaduch w małym pomieszczeniu.

Jakie konteksty $\mathrm{w}$ realizacji otwiera zastosowanie sceny obrotowej?

Scenę można tu potraktować także dosłownie, bo przecież przenosi nas ona $\mathrm{z}$ miejsca w miejsce, z sypialni do sali lekcyjnej, z polany na łące do kościoła. Ale tak, przede wszystkim konsekwentnie podczas spektaklu wykorzystywana scena jest przecież metaforą śruby. Z aktu na akt nasi bohaterowie są coraz bardziej „dokręcani”, coraz bardziej wirują w labiryncie grozy. Chyba w żadnym innym przedstawieniu ta techniczna konstrukcja tak świetnie się nie sprawdziła w interpretacyjnym polu dzieła.

W przeciwieństwie do minimalistycznej koncepcji wystroju scenicznego, kostiumy zostały zaprojektowane z rozmachem, zwłaszcza stroje kobiece stanowią wyraźne odniesienie do epoki wiktoriańskiej, w której toczy się akcja. Stroje duchów odbiegają od strojów ludzi. Panna Jessel prowokuje kostiumem, który ukazuje elementy damskiej garderoby chowane w XIX wieku skrzętnie pod suknią. Przezroczysta krynolina pozwala dostrzec kuszącą cielesność zjawy. Quint wygląda natomiast zdecydowanie nowocześnie (mnie się kojarzy z motocyklistą) i wyróżnia się specjalnym makijażem. Jakie informacje kostiumy i kolory przekazują o charakterach postaci?

Nie chcieliśmy wyjmować tej opery z jej wiktoriańskiego tła. Przepych strojów intrygująco współgra z projekcjami i lekką scenografią. Mówi Pani o lekko roznegliżowanej pannie Jessel. Nie zapominajmy, że w czasach wiktoriańskich były dwa modele kobiet: kobiety uległej, ciepłej, takiej mocno udomowionej, dzisiaj powiedzielibyśmy, że kury domowej. Drugi model kobiety to kobieta wyzwolona seksualnie. Czy poprzednia guwernantka jest jedną, czy drugą? Czy jako duch jest inną kobietą, niż była za życia? Jest zatem ubrana inaczej, ucharakteryzowana inaczej. Jest bardziej demoniczna, na pewno, podobnie jak Quint, istna personifikacja zła. Makijaż miał podkreślić niezwyczajność obu zmarlych istot, duchów, podkreślił też sposób ich postrzegania przez guwernantkę.

W jaki sposób projekcje multimedialne przygotowane przez Ewę Krasucką komentują i uzupełniają muzyczną narrację oraz akcję sceniczną?

Projekcje zawsze są dopełnieniem opowieści i scenografii. Jak już mówiłem, dodały lekkości mrocznej, ponurej, wiktoriańskiej atmosferze. Przenoszą nas bezkonfliktowo z miejsca na miejsce, przez swą delikatną sugestię zabierają dosłowność miejsca akcji, wzbogacają przestrzeń sceniczną o symboliczność. Poszczególne projekcje są tu właśnie wizualnymi znakami wydarzeń, napięcia. 


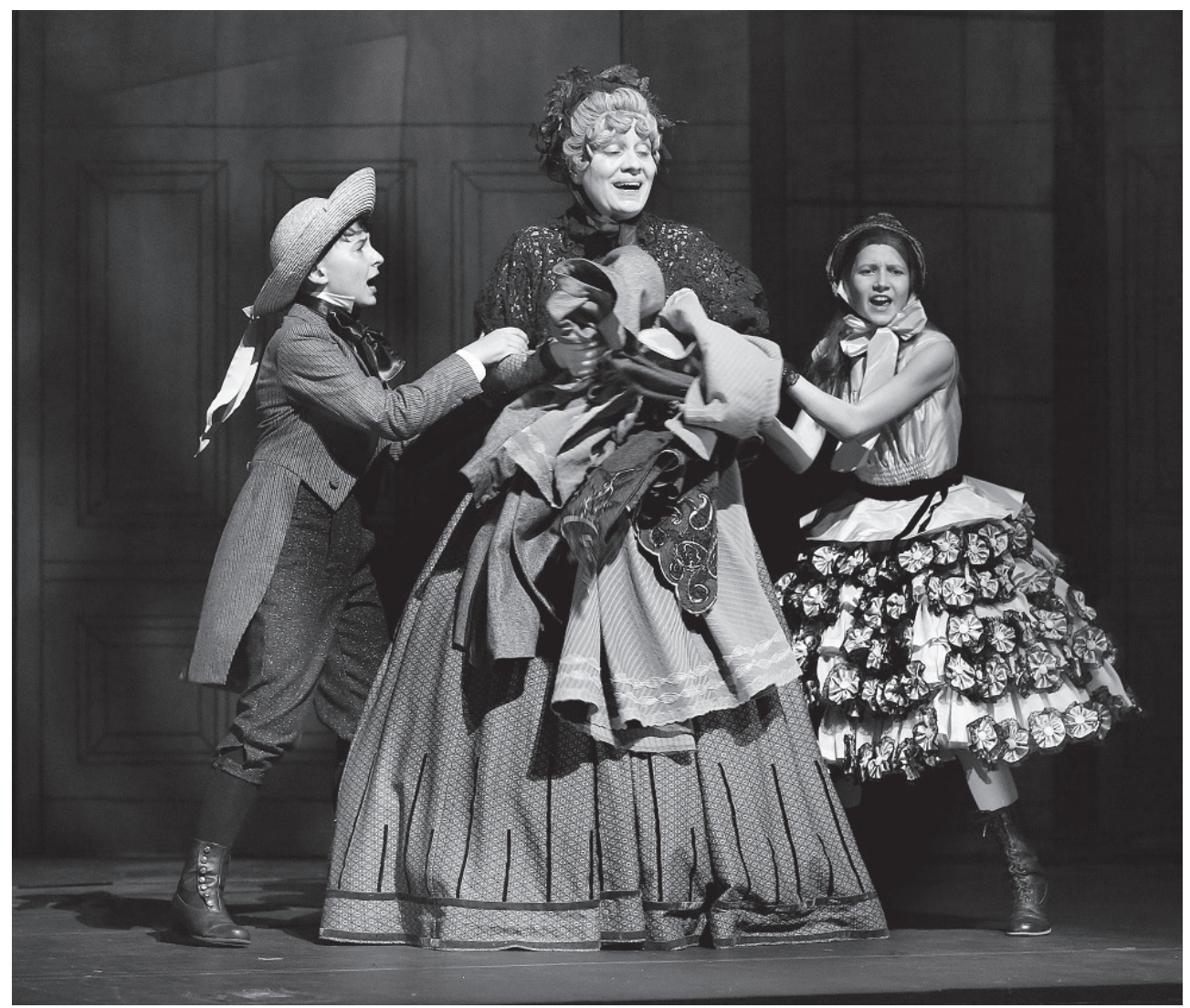

Dokręcanie śruby. Fot. Marek Grotowski

Opera Brittena stanowi wyzwanie dla dziecięcych wykonawców, którzy występują $\mathrm{w}$ niej nie jako postaci epizodyczne, ale w rolach pierwszoplanowych. Dochodzi do tego aspekt psychologiczny, ponura, kryjąca erotyczne tajemnice atmosfera. Barbara Halec, która przygotowywała dzieci do spektaklu, miała chyba niełatwe zadanie?

Dzieci, które grają w Dokręcaniu śruby, są bardzo zdolnymi młodymi śpiewakami. Ale przecież grają dramatyczne role, z seksualnym podtekstem, musiały dla dobra własnych kreacji zrozumieć, albo przynajmniej próbować zrozumieć, co właściwie zdarzyło się $\mathrm{w}$ domu odtwarzanych przez nie postaci. Bez tego nie byłyby wiarygodne. Gdyby to były epizody... Ale nie, to były pierwszoplanowe role. Do tego młodzi śpiewacy grali przed dużą publicznością. To było prawdziwe wyzwanie i tu kłaniam się nisko i Barbarze Halec, i Natalii Babińskiej, i oczywiście odtwórcom ról dzieci za pełen sukces.

Nowela Jamesa jest niepowtarzalna ze względu na swoją niejednoznaczność. Duchy można traktować jako wytwór wyobraźni guwernantki lub zjawy istniejące w świecie przedstawionym „realnie”, poza umysłem młodej kobiety. Guwernantka może być odbierana jako heroina, tocząca dramatyczną walkę o dusze dzieci, lub jako niezrównoważona psychicznie, ulegająca erotycznym fantazjom kobieta. Czy ta dwuznaczność w jakiś sposób zostaje w wersji szczecińskiej zachowana? 
Jak najbardziej. Ten utwór daje świetne pole do interpretacji, tak literaturoznawcom, jak i krytykom teatralnym czy operowym w naszym przypadku. Ale są i inne konteksty, gdzie możemy ulokować naszą bohaterkę, to mogą być nawet czasy współczesne. Może znów uruchamia się śruba i z grzecznej panny powoli wyłania się drapieżna dusza? Może te dwie natury walczą ze sobą w obliczu nowych realiów, po przyjeździe do wiejskiej posiadłości? Przecież człowiek w obliczu zła, tajemnicy, strachu staje się inny. Nie zapominajmy też tu o dwóch modelach kobiety wiktoriańskiej. Nie chcieliśmy w spektaklu dawać prostej odpowiedzi.

Pierwowzór literacki oraz opera stawiają pytanie o rzeczy, o których także dzisiaj trudno rozmawiać: dziecięcą niewinność, homoseksualizm i pedofilię, granice moralności. Wizji reżyserskiej Natalii Babińskiej zarzuca się zachowawcze podejście do tematu, przejawiające się na przykład w pominięciu intymnej relacji Milesa i Quinta. Inni krytycy chwalą ją za dyskretne sygnalizowanie spraw niedopowiedzianych. Co Pan sądzi o potraktowaniu tych tematów w realizacji?

Zachowawcze? Nie zgadzam się z tą opinią. Konteksty są bardzo czytelne, często ruch ciał wręcz ewidentny, choć faktycznie, bardzo chcieliśmy uciec od dosłowności i poszerzyć pole interpretacji. Chcieliśmy też uniknąć wulgarności. Nie była potrzebna. Ten spektakl nie miał prowokować, miał zmusić do myślenia. Ale jeśli ktoś nie odczytał stosunków Milesa z Quintem jako erotycznych, to może odczytał inaczej? Może Quint to alter ego Milesa, chłopca, w którym rodzi się dorosłość, seksualność, ale i to, co z dojrzewaniem może być związane: wybór drogi, którą chce się podążać w życiu, czy też wejście na ścieżkę zła.

Szczecińską inscenizację określa się jako bardzo udaną. Jacek Marczyński w „Ruchu Muzycznym” wyraża się z uznaniem o pełnej dramatyzmu interpretacji zaprezentowanej przez Jerzego Wołosiuka i szczecińską orkiestrę. Recenzenci podkreślają wysoki poziom wokalny spektaklu i chwalą sposób, w jaki soliści kreowali sceniczne postaci. Czy może Pan zdradzić, z których scen jest Pan szczególnie zadowolony pod względem muzycznym i aktorskim?

Najbardziej podobają mi się: scena w pociągu, scena $\mathrm{z}$ duchem, który miota się pomiędzy ścianami budynku, i scena z kościoła. Są niebywale plastyczne, a przecież plastyczność jest niewątpliwym i nieodłącznym atrybutem Dokręcania śruby. Są też bardzo dynamiczne reżysersko. Lubię takie nowe, ciekawe rozwiązania sceniczne.

Kiedy możemy zobaczyć kolejne przedstawienia opery?

Już 5 listopada 2016, oczywiście w Operze na Zamku w Szczecinie. 6 listopada obejrzą je studenci w ramach naszego cyklu OPERAcja STUDENT, podczas której zachęcamy, między innymi ceną naturalnie, brać studencką do zawitania w nasze progi. Potem wystawiamy Dokręcanie śruby 6 i 7 maja 2017.

Gdzie jeszcze poza Szczecinem będzie można zobaczyć operę? Jesteśmy w trakcie rozmów na ten temat.

Czy planuje Pan rejestrację przedstawienia na płycie DVD? Byłaby to niewątpliwie radosna wiadomość dla milośników Brittena mieszkających daleko od Szczecina. 
Taka rejestracja jest możliwa i ma sens jedynie wtedy, gdy spektakl filmowany jest z kilku kamer, a wszystkim zawiaduje reżyser (realizator). Na razie nie mamy na to pieniędzy. Jeżeli uda mi się je zdobyć, a wierzę w to mocno - oczywiście melomani dostaną wersję Dokręcania śruby na DVD. Na razie zapraszam do Opery na Zamku.

Wywiad przeprowadziła Katarzyna Szczerbowska-Prusevicius* badawcze dotyczą związków literatury z muzyką. E-mail: Katarzyna.Szczerbowska-Prusevicius@umk.pl. 